\title{
Methodology for assessing the role of mangroves in trace metal(loid) filtration to develop a mechanism of payments for environmental services for mangroves in Vietnam
}

Nguyễn Thành Nho

Trương Văn Vinh

Phạm Thu Thủy 

Working Paper 268

\section{Methodology for assessing the role of mangroves in trace metal(loid) filtration to develop a mechanism of payments for environmental services for mangroves in Vietnam}

Nguyễn Thành Nho

Nguyen Tat Thanh University

Trương Văn Vinh

Ho Chi Minh City University of Agriculture and Forestry

Phạm Thu Thủy

Center for International Forestry Research (CIFOR) 
Working Paper 268

C 2020 Center for International Forestry Research

(c) (i) Content in this publication is licensed under a Creative Commons Attribution 4.0 International (CC BY 4.0), http://creativecommons.org/licenses/by/4.0/

DOI: $10.17528 /$ cifor/007886

Nguyễn TN, Trương VV and Phạm TT. 2020. Methodology for assessing the role of mangroves in trace metal(loid) filtration to develop a mechanism of payments for environmental services for mangroves in Vietnam. Working Paper 268. Bogor, Indonesia: CIFOR.

Translation of: Nguyễn TN, Trương VV và Phạm TT. 2020. Phương pháp đánh giá vai trò của rừng ngập mặn trong việc lọc vết kim loại. Báo cáo chuyên đề 265. Bogor, Indonesia: CIFOR.

\section{CIFOR}

JI. CIFOR, Situ Gede

Bogor Barat 16115

Indonesia

$\mathrm{T}+62(251) 8622-622$

$F+62(251) 8622-100$

E cifor@cgiar.org

\section{cifor.org}

We would like to thank all funding partners who supported this research through their contributions to the CGIAR Fund. For a full list of the 'CGIAR Fund' funding partners please see: http://www.cgiar.org/our-funders/

Any views expressed in this publication are those of the authors. They do not necessarily represent the views of CIFOR, the editors, the authors' institutions, the financial sponsors or the reviewers. 


\section{Contents}

Acronyms

$\mathbf{v}$

Acknowledgement

Summary

1 Introduction 1

2 Indices for assessing water quality and sediment 3

2.1 Water quality indices 3

2.2 Indices for metal(loid) pollution in sediment 3

3 Research and methodology to assess the role of mangroves 7

$\begin{array}{lll}3.1 & \text { Literature review } & 7\end{array}$

$\begin{array}{ll}3.2 & \text { Related stakeholder interviews }\end{array}$

3.3 Field investigations and selection of study sites 8

3.4 Control and intervention site approach and selection of study sites 8

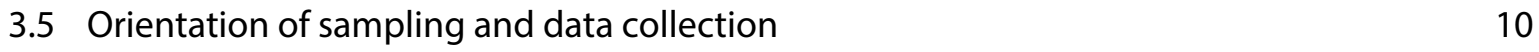

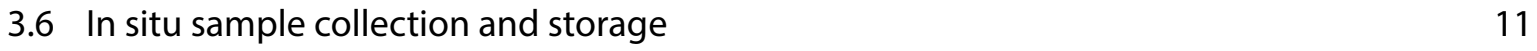

$\begin{array}{ll}\text { 3.7 Data analysis } & 12\end{array}$

4 Cost of monitoring and assessment $\quad 15$

5 Lessons learned $\quad 18$

6 Conclusion $\quad 19$

$\begin{array}{lr}\text { References } & 20\end{array}$ 


\section{List of figures and tables}

\section{Figures}

1 Research process and methodology in Hai Phong. $\quad 7$

2 Sample collection sites on the Cam River (without mangroves) and

Da Bac-Bach Dang River (with mangrove forest). 9

3 Filtering water samples and measuring physical and chemical parameters 12

4 Sampling bottom sediments 13

5 Collection of sediment at the mudflat 16

\section{Tables}

1 Parameters for calculating VN_WQI 3

2 Indices for metal(loid) pollution in sediment.

3 Sampling collection in Hai Phong.

4 Method of sample collection.

5 Analytical methods in the laboratory.

6 Results and implications for the development of a PFES mechanism. 14

7 Findings from the Can Gio mangrove, Ho Chi Minh City. 16 


\section{Acronyms}

\begin{tabular}{|c|c|}
\hline As & Arsenic \\
\hline BOD & Biochemical oxygen demand \\
\hline $\mathrm{Cd}$ & Cadmium \\
\hline CF & Contamination factor \\
\hline COD & Chemical oxygen demand \\
\hline $\mathrm{Cr}$ & Chromium \\
\hline $\mathrm{Cu}$ & Copper \\
\hline DDTs & Synthetic insecticides belonging to the chloride compound family \\
\hline DO & Dissolved oxygen \\
\hline EF & Enrichment factor \\
\hline Eh & Redox potential of a solution \\
\hline $\mathrm{Hg}$ & Mercury \\
\hline HNO3 & Nitric acid \\
\hline ICP-MS & Inductively coupled plasma mass spectrometry \\
\hline lgeo & Geo-accumulation index \\
\hline ISO & International Organization for Standardization \\
\hline $\mathrm{Mn}$ & Manganese \\
\hline $\mathrm{NH} 4+$ & Ammonium ion \\
\hline NIST & National Institute of Standards and Technology (USA) \\
\hline $\mathrm{N}-\mathrm{NH} 4+$ & Nitrogen-Ammonium \\
\hline $\mathrm{N}-\mathrm{NO} 2$ & Nitrogen- Nitrite \\
\hline $\mathrm{N}-\mathrm{NO} 3$ & Nitrogen-Nitrate \\
\hline $\mathrm{Pb}$ & Lead \\
\hline PE & Polyethylene \\
\hline PFES & Payment for forest environmental services \\
\hline $\mathrm{pH}$ & Index of the acidity or basicity of an aqueous solution \\
\hline PLI & Pollution load index \\
\hline P-PO4 & Phosphorus-Orthophosphate \\
\hline PTFE & Polytetrafluoroethylene \\
\hline SWAMP & Sustainable Wetlands Adaptation and Mitigation Program \\
\hline TCVN & Vietnamese Technical Standard \\
\hline $\mathrm{TN}$ & Total nitrogen \\
\hline TOC & Total organic carbon \\
\hline TP & Total phosphorus \\
\hline T-test & Students'T distribution statistics test \\
\hline USAID & The United States Agency for International Development \\
\hline VNFF & Vietnam Forest Protection and Development Fund \\
\hline WQI & Water quality index \\
\hline $\mathrm{Zn}$ & Zinc \\
\hline
\end{tabular}




\section{Acknowledgement}

This study is part of CIFOR's Global Comparative Study on REDD+ (www.cifor.org/gcs) and the Sustainable Wetlands Adaptation and Mitigation Program (SWAMP). We are sincerely grateful to the Norwegian Agency for Development Cooperation (NORAD), the United States Agency for International Development (USAID) and the CGIAR Research Program on Forests, Trees and Agroforestry (CRP-FTA) for their financial support for this research. We would also like to express our special thanks to Mr. Pham Van Thanh, Mr. Pham Van Trung of the Vietnam Forest Protection and Development Fund (VNFF), the staff of the Hai Phong City Forest Protection and Development Fund and the staff of the Vietnam Forest Protection Department for their invaluable support and assistance to the research team in carrying out the project. 


\section{Summary}

One of the important environmental services mangroves provide is trapping suspended matter and sediments that carry trace metal(loid)s and organic waste from natural processes and human activities. Uniquely located, mangroves play a vital role in various functions, including the sedimentation, absorption, accumulation and transformation of pollutants emitted from residential areas, harbors and industrial zones before they discharge into the sea. Therefore, mangroves are considered highly efficient natural filters and a physical and biological storage sinks for pollutants, particularly metal(loid)s.

However, this critical function of mangroves still receives little attention, and there has been no effort to incorporate it into existing policies. Consequently, as yet no financial mechanisms for conservation or payment for this environmental service have been put in place. In addition to the difficulty of identifying buyers, another challenge is providing evidence of a mangrove's role in improving water quality to the service users. Moreover, when the environmental service being paid for is improvement of water quality, a proper tool and methodology must be in place for assessing and monitoring this service.

This document aims to provide an understanding of the scientific methodology that can be employed to demonstrate, monitor and assess mangrove-relevant environmental services by using case studies of mangroves in Hai Phong City and the Can Gio district of Ho Chi Minh City in Vietnam. In addition to previous work, this methodology evaluates the water purification services of mangroves in the context of existing policies on payment for forest environmental services in Vietnam, and discusses lessons learned, and funding requirements for effective assessment, evaluation and monitoring of the service. The findings contribute to identifying users and buyers of mangrove environmental services and developing implementation and monitoring mechanisms for payment for forest environmental services (PFES) through the application of environmental indices. The document is made in the hope that future studies can apply its methodology in other regions of the country to develop a database for evaluating the roles of mangroves throughout Vietnam. 



\section{Introduction}

Payment for forest environmental services (PFES) is one of the ten largest achievements of the agriculture and forestry sector in Vietnam in the past decade. Contributing $22 \%$ of total forestry sector investment, PFES is considered one of the sector's sustainable sources of income. Increasing PFES revenue is also a forestry sector priority for the next decade. Vietnam Decree 99 and Decision 147 identify five types of forest environmental services to be implemented in the Vietnam PFES policy, including mangrove-related environmental services. However, the payment mechanism for mangrove environmental services in Vietnam remains limited. It fails to recognize various potentially important services, such as water supply and water purification through metal(loid) filtration (Pham et al. 2020).

Mangroves mainly occur in coastal areas, which are directly affected by tidal regimes. Those areas serve as transitional zones for water and material transportation from the mainland to the sea. Berner and Raiswell (1983) showed that around 75 - 90\% of total material flows in water were captured in coastal areas. These transition zones, especially those with mangroves, can change the water's physical and chemical properties, such as $\mathrm{pH}$ value, conductivity, salinity, total suspended solids, total dissolved solids and dissolved oxygen. The slope gradients of terrain gradually decrease towards the sea, which reduces the flow of water and pollutants. The sedimentation process for material, including trace metal(loid)s, is more efficient as only parts of those trace metal(loid)s are exposed to the sea (Salomons et al. 1988). Changes in physical and chemical properties can affect the movement of metal(loid)s in surface sediments and the concentration of free metal(loid) ions in the water. In mangrove sediment, trace metal(loid)s can be adsorbed, precipitated, co-precipitated and absorbed in mangrove plants (Wood and Shelley 1999; Yu et al. 2001).

Mangrove species can absorb pollutants in their bodies (Marchand et al. 2016; Thanh-Nho et al. 2019), retain suspended matter, and transport oxygen from the aerial parts to the rhizosphere, which provides a favorable environment for the rhizosphere, promotes several chemical and biochemical reactions, and enhances trace metal(loid) accumulation processes (Kadlec et al. 2000). A high concentration of sulfide in mangroves also facilitates the precipitation and fixation of trace metal(loid)s (Dunbabin and Bowmer 1992). In contrast, through the radial oxygen loss (ROL) process, the rhizosphere is ventilated and increases trace metal(loid) mobility because of the oxidation and dissolution of sulfide. ROL also leads to the formation of iron (Fe) plaque, which provides additional electron chemical bonds to increase trace metal(loid)s in the root surface (Cheng et al. 2013). Mangroves have developed and adapted physiologically, morphologically and anatomically through such processes as salt regulation, aerosols and highly specialized root systems (e.g. prop roots, kneed roots, snorkel-like roots, or breathing roots) to adapt to anoxic and saltwater environments (Marchand et al. 2004). Adaptive changes in mangroves, coupled with extreme growth conditions (extreme environment and pollution) have proven that using mangroves to purify polluted water and sediment is highly promising. In this regard, the Avicennia and Rhizophora species have been widely used as biological machines to absorb trace metal(loid) s (Kamaruzzaman et al. 2011; Thanh-Nho et al. 2019). Mangrove roots can act as a natural fence to trap most trace metal(loid)s and reduce their movement to other parts of the trees (Yim and Tam 1999). Different mangroves types can have different capacities to absorb trace metal(loid)s (Agoramoorthy et al. 2008; MacFarlane et al. 2003). Previous literature has used mangrove plants and their sediments as reliable biological indicators to assess metal(loid) contamination and pollution (Defew et al. 2005). Also, trace metal(loid)s are enriched during the decomposition of organic matter and can be absorbed in the water column at high tide and in surface sediments by organic molecules or decomposing litterfall (Vinh et al. 2020). 
Although many scientists around the world have proven the role of mangroves in metal(loid) filtration, four major questions for policymakers and mangrove PFES development projects in Vietnam remain:

1. How can we demonstrate and prove that mangroves can purify pollutants in the water?

2. What methodology(ies) can be used to measure and prove this argument?

3. What is the cost of measuring and monitoring mangrove environmental services? Is it suitable for available PFES funds? What solutions are there for minimizing the cost of assessing and monitoring?

4. Who can conduct such methodology(ies)? And what skills do they require?

This document aims to answer these questions. It describes the methodology for policymakers, NGOs, research organizations and PFES-related projects to research, evaluate and monitor the role of mangrove in filtering metal(loid)s, thereby providing useful input and information for the development and implementation of PFES for mangroves. Using the case study in Hai Phong under the SWAMP project funded by USAID', the authors describe a step-by-step process for conducting and implementing the methodology and provide lessons learned for relevant future research. We hope that future researchers can apply the methodology in other regions of the country, and develop a database to evaluate the role of mangroves in Vietnam.

1 With regard to the case study in Hai Phong City, the objectives of the study were to assess: i) water quality, ii) the current state of metal(loid) pollution in the water, iii) surface sediment; and iv) the role of mangrove ecosystems in accumulating and reducing the levels of pollutants in the water. 


\section{Indices for assessing water quality and sediment}

\subsection{Water quality indices}

To assess water quality, governments and scientists around the world often use the Water Quality Index (WQI), which is:

- A combination index calculated from several water quality parameters, determined through a mathematical formula

- For the measurement of water quality and represented on a scale, based on results of parameters including $\mathrm{pH}$ value, total organic carbon (TOC), dissolved oxygen (DO), total $\mathrm{NH}_{4}^{+}$, total nitrogen (TN), total phosphorous (TP), and concentration of dissolved metal(loid) ions, pesticides, and microbiological factors.

In the context of Vietnam and the study sites in Hai Phong City, the WQI will be calculated based on Vietnam Environment Administration guidelines (http://www.monre.gov.vn). Accordingly, the parameters used to calculate the VN_WQI are divided into five groups (see Table 1). Data used to calculate VN_WQI needs to consist of at least three of the five groups, and must have parameters from group IV. In group IV, at least three parameters are used for calculation. In the case of water affected by characterized pollution, it is necessary to use the corresponding characteristic parameter group(s) in the calculation. For example, for water bodies with pesticide pollution, parameter group II indices must be included. For water bodies subjected to metal(loid) breakdown, the index's calculation must contain indices from group III.

Table 1. Parameters for calculating VN_WQI

\begin{tabular}{|c|c|}
\hline Parameter & Indices \\
\hline Group I & $\mathrm{pH}$ value \\
\hline Group II & $\begin{array}{l}\left.\text { Pesticides: Aldrin, BHC, Dieldrin, DDTs ( } p, p^{\prime}-D D T, p, p^{\prime}-D D D, p, p^{\prime}-D D E\right), \text { Heptachlor and } \\
\text { Heptachlor epoxide. }\end{array}$ \\
\hline Group III & Metal(loid)s: As, Cd, Pb, $\mathrm{Cr}^{6+}, \mathrm{Cu}, \mathrm{Zn}, \mathrm{Hg}$ \\
\hline Group IV & Nutrient and organic compounds: $\mathrm{DO}, \mathrm{BOD}_{5^{\prime}} \mathrm{COD}, \mathrm{TOC}, \mathrm{N}-\mathrm{NH}_{4}^{+}, \mathrm{N}-\mathrm{NO}_{3^{\prime}}, \mathrm{N}-\mathrm{NO}_{2}, \mathrm{P}^{\prime} \mathrm{PO}_{4}$ \\
\hline Group V & Microbial load: Coliform, E. Coli. \\
\hline
\end{tabular}

\subsection{Indices for metal(loid) pollution in sediment}

Sediment is a solid material that is deposited by geological or other natural processes. The background composition of sediment consists of particles of different sizes, from large rocks, pebbles and sand to suspended or dissolved matter. Sediment particles can either rest in one place or moved to and deposited in another place by water, wind or gravity. The deposition process of materials to create sediment is called sedimentation. Sedimentation is a mainly physical process in which solid particles are settled by gravity. In coastal areas, precipitation of solids occurs due to physical and chemical reactions with seawater. Seas, rivers and lakes are common areas where sediment accumulates. Deltas are a typical example of river sedimentation. In a previous study in the Can Gio mangrove forest in Ho Chi Minh City, MacKenzie et al. (2016) identified annual vertical accretion rates of sediment in fringe and interior mangroves at $1.06 \pm 0.12 \mathrm{~cm} /$ year and $0.99 \pm 0.09 \mathrm{~cm} /$ year, respectively. 
In recent years, the assessment of sediment pollution by trace metal(loid) compositions has received increased interest from academia (Costa-Boddeker et al. 2017; Strady et al. 2017; Sundaramanickam et al. 2016). Several indices are used to assess the level of impacts and potential risks from metal(loid)s in sediment to the environment and the broader ecosystem in river and coastal areas. In this document, four indices are considered in studying and assessing metal(loid) pollution in sediment in estuaries and coastal areas (see Table 2).

Table 2. Indices for metal(loid) pollution in sediment.

\begin{tabular}{ll}
\hline Indices & Descriptions \\
\hline EF-Enrichment & A useful tool to identify trace metal(loid)s in the surface sediment that can \\
Factor & come from natural or anthropogenic activities (Zhang and Liu 2002). \\
Trace metal(loid) concentrations in sediment are normalized to Aluminum & (Al) to compensate for natural variability due to changes in particle size (e.g. \\
mineral composition) and to identify any metal(loid) contribution from human \\
activities. Al is used as a reference because it is one of the basic elements \\
formed in the earth's crust and mainly exists in the form of alumina-silicate in \\
coastal sediment (Chen et al. 2007). In addition, Al is likely to be weathered and \\
affected by human activities (Sinex and Wright 1988). EF is calculated using \\
the formula (Dragović et al. 2008) as follows:
\end{tabular}

$$
E F=\frac{\left(\frac{[\mathrm{Me}]}{[\mathrm{Al}]}\right)_{\text {sediments }}}{\left(\frac{[\mathrm{Me}]}{[\mathrm{Al}]}\right)_{\text {crust }}}(1-1)
$$

Where, $[\mathrm{Me}]_{\text {soil }}$ and $[\mathrm{Me}]_{\text {crust }}$ are the concentration of metal(loid)s in the sediment and in the continental crust, respectively. $[A]_{\text {sediment }}$ and $[A l]_{\text {crust }}$ are the concentrations of $\mathrm{Al}$ in the sediment and the continental crust, respectively. The concentration level of each metal(loid) in the upper earth crust is based on the publication of Wedepohl (1995). The concentration value is in $\mathrm{mg} \mathrm{kg}^{-1}$. To assess the degree of metal(loid) pollution, the EF is classified into six enrichment categories following Taylor (1964), as shown in Table 2.1.

Table 2.1. Classification of metal(loid) enrichment.

\begin{tabular}{cll}
\hline Level & Value & Categorization \\
\hline 0 & $E F \leq 1$ & No enrichment \\
\hline 1 & $1 \leq E F \leq 3$ & Minor enrichment \\
\hline 2 & $3 \leq E F \leq 5$ & Moderate enrichment \\
\hline 3 & $5 \leq E F \leq 10$ & $\begin{array}{l}\text { Moderately severe } \\
\text { enrichment }\end{array}$ \\
\hline 4 & $10 \leq E F \leq 25$ & Severe enrichment \\
\hline 5 & $25 \leq E F \leq 50$ & Very severe enrichment \\
\hline 6 & $50 \leq E F$ & $\begin{array}{l}\text { Extremely severe } \\
\text { enrichment }\end{array}$ \\
\hline
\end{tabular}


Table 2. Continued

\begin{tabular}{|c|c|c|c|}
\hline Indices & \multicolumn{3}{|c|}{ Descriptions } \\
\hline $\begin{array}{l}\text { CF-Contamination } \\
\text { Factor }\end{array}$ & \multicolumn{3}{|c|}{$\begin{array}{l}\text { The physical, chemical and geochemical characteristics of sedim } \\
\text { indicators for assessing pollution levels and identifying pollution } \\
\text { contamination factor (CF) is used as an index for sediment pollut } \\
\text { specific pollutant. It is represented by a ratio between the conce } \\
\text { metal(loid) to the value of a reference metal(loid) (Wedepohl } 19\end{array}$} \\
\hline & & $C F=\frac{[M e]_{S}}{[M e]_{c}}$ & $(1-2)$ \\
\hline & \multicolumn{3}{|l|}{ Where: } \\
\hline & \multirow{2}{*}{\multicolumn{3}{|c|}{$\begin{array}{l}{[\mathrm{Me}]_{\text {sediments }} \text { is the concentration level of a given metal(loid) in }} \\
{[\mathrm{Me}]_{\text {crust }} \text { is the concentration level of that metal(loid) in the cor }} \\
\text { (Wedepohl 1995). The degree of metal(loid) pollution is classifiec } \\
\text { contamination levels, as shown in Table } 2.2 \text { (Hakanson 1980): } \\
\text { Table 2.2. Classification on metal(loid) contamination. }\end{array}$}} \\
\hline & & & \\
\hline & No. & Contamination level & CF value \\
\hline & 1 & Low & $<1$ \\
\hline & 2 & Moderate & $1-3$ \\
\hline & 3 & Considerable & $3-6$ \\
\hline & 4 & Very High & $>6$ \\
\hline
\end{tabular}

PLI-Pollution Load Index
The pollution load index (PLI) is an estimated average value of polluted sediment due to metal(loid) accumulation (Table 2.3). According to (Tomlinson et al. 1980), PLI is employed as an integrated tool to assess the pollution based on the concentration of metal(loid)s using the formula:

$$
P L I=\left(C F_{1} \times C F_{2} \times C F_{3} \times \ldots \times C F_{n}\right)^{\frac{1}{n}} \quad(1-3)
$$

Where:

$\boldsymbol{n}$ is the number of metals causing pollution at the studied site, and $\boldsymbol{C F}$ is the Contamination Factor.

Table 2.3. Classification of metal(loid) pollution level in estuaries by PLI.

\begin{tabular}{clc}
\hline No. & \multicolumn{1}{c}{ Pollution level } & PLI value \\
\hline 1 & No pollution & $<1$ \\
\hline 2 & Only at a baseline level of pollution & $=1$ \\
\hline 3 & Serious deterioration in ecosystems & $>1$ \\
\hline
\end{tabular}


Table 2. Continued

\begin{tabular}{|c|c|c|c|}
\hline Indices & \multicolumn{3}{|c|}{ Descriptions } \\
\hline \multirow[t]{16}{*}{$\begin{array}{l}\text { Igeo-Geo- } \\
\text { accumulation Index }\end{array}$} & \multicolumn{3}{|c|}{$\begin{array}{l}\text { A quantitative measurement to assess the extent of contamination in sediment, } \\
\text { the index can identify the pollution in sediment caused by organic and inorganic } \\
\text { matter by comparing the current and pre-industrial concentrations of trace } \\
\text { metal(loid)s. Hence, an increase in the current level is predicted to be caused by } \\
\text { human activities. The formula is as follows: }\end{array}$} \\
\hline & \multicolumn{3}{|c|}{$I_{g e o}=\log _{2} \frac{C_{n}}{B_{n} \times 1.5}(1-4)$} \\
\hline & \multicolumn{3}{|l|}{ Where: } \\
\hline & \multicolumn{3}{|c|}{$\mathrm{C}_{n}$ : concentration of target element to be identified in the sediment } \\
\hline & \multicolumn{3}{|c|}{$\begin{array}{l}B_{n}: \text { the value of geochemical background of that element in the continent crust } \\
\text { (Wedepohl 1995). }\end{array}$} \\
\hline & \multicolumn{3}{|c|}{$\begin{array}{l}\text { 1.5: constant, a baseline background correction factor for organism influence } \\
\text { (to minimize possible variability in the background values). }\end{array}$} \\
\hline & \multicolumn{3}{|c|}{ The $I_{g e o}$ is classified under seven levels (Table 2.4). } \\
\hline & \multicolumn{3}{|c|}{ Table 2.4. Classification of pollution level by $\boldsymbol{I}_{g e o}$. } \\
\hline & Level & Value & Categorization \\
\hline & 0 & $I_{g e o} \leq 0$ & \multirow{4}{*}{$\begin{array}{l}\text { Uncontaminated } \\
\text { Uncontaminated to } \\
\text { moderately Contaminated } \\
\text { moderately to heavily } \\
\text { Contaminated heavily }\end{array}$} \\
\hline & 1 & $0 \leq I_{g e o} \leq 1$ & \\
\hline & 2 & $1 \leq I_{g e o} \leq 2$ & \\
\hline & 3 & $2 \leq I_{g e o} \leq 3$ & \\
\hline & 4 & $3 \leq I_{g e o} \leq 4$ & \multirow{3}{*}{$\begin{array}{l}\text { Highly polluted } \\
\text { Heavily to extremely } \\
\text { contaminated } \\
\text { Extremely high }\end{array}$} \\
\hline & 5 & $4 \leq I_{g e o} \leq 5$ & \\
\hline & 6 & $5<I_{g e o}$ & \\
\hline
\end{tabular}




\section{Research and methodology to assess the role of mangroves}

Step-by-step research in Hai Phong is shown in Figure 1. The case study in Hai Phong applies a mix of qualitative and quantitative methods and integrates the data collection for socio-economic and basic physical and chemical indices.

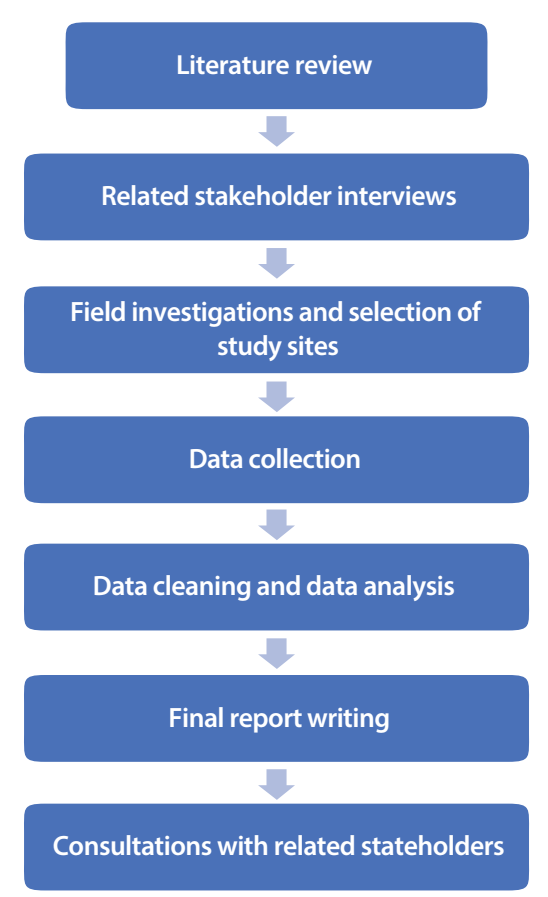

Figure 1. Research process and methodology in Hai Phong.

\subsection{Literature review}

We conducted a literature review to understand the political and socioeconomic background of and forest protection and development trends in the study areas. Various things were reviewed for the study, including: all reports on mangrove development in Hai Phong; socioeconomic reports; central- and local-level policies and strategies for socioeconomic development and environmental protection; remote sensing data; international and Vietnamese reports on the potential to develop a PFES mechanism for mangroves in Vietnam; and reports on environmental hotspots in Hai Phong. The methodology enabled the research team to: i) identify potential mangrove environmental services in Hai Phong; and (ii) list potential buyers and sellers for each environmental service (see the publication by Pham et al. (2020)).

\subsection{Related stakeholder interviews}

We conducted interviews with all related stakeholders, including government institutions, civil society organizations and representatives of buyers of environmental services in Hai Phong, to investigate current priorities of the provincial government, sources of water pollution, opportunities and challenges for the development of a PFES mechanism in Hai Phong, as well as the role of mangroves in metal(loid) filtration (See the publication by Pham et al. (2020)). 


\subsection{Field investigations and selection of study sites}

Because of financial limitations, we needed to identify the most representative study sites that could explicitly demonstrate the complementarities of mangroves. From the literature review and stakeholder interviews, we came up with a list of potential studied sites for collecting data, then conducted field investigations to select the most appropriate places from the list.

\subsection{Control and intervention site approach and selection of study sites}

One of the challenges in developing policies for mangrove PFES is to demonstrate PFES and mangrove complementarities. In other words, the main question to answer was: “Whether sites dominated by mangroves have better water quality than those without mangroves when comparing the two areas together". This required careful selection of study sites to ensure representativeness and to adequately and correctly demonstrate the functions of mangroves. To determine the extent of water pollution and the role of mangroves in reducing pollutants, we would assess water quality at water inlets, at sites with and without mangroves, and in estuaries. In addition, we would also compare the water quality in those locations to assess the quality of water before and after flowing through the mangrove. The literature review, stakeholder interviews and field investigations showed the two most appropriate sites for these objectives to be the Cam river (without mangroves) and Da Bac-Bach Dang river (with dominant mangroves). According to Pham et al. (2020), there are several primary pollution sources in the two selected areas, including ports, fishing ports, tourist ports, waterborne transport industries, mineral extraction, iron and steel metallurgy industries, oil companies, shipbuilding industries, water supply companies, thermal power industries, coastal industrial parks and economic zones, agroforestry-aquatic product processing industries, residential areas, and agriculture, forestry and fisheries activities.

With the available funding, we collected samples at seven sites in the Cam and Da Bac-Bach Dang rivers in Hai Phong (see Table 3 and Figure 2).

Table 3. Sampling collection in Hai Phong.

\begin{tabular}{|c|c|c|c|}
\hline $\begin{array}{l}\text { River } \\
\text { location }\end{array}$ & $\begin{array}{l}\text { Sampling } \\
\text { site }\end{array}$ & Description & Note \\
\hline \multirow{2}{*}{$\begin{array}{l}\text { Upstream } \\
\text { - before } \\
\text { water enters } \\
\text { areas with } \\
\text { extensive } \\
\text { domestic } \\
\text { activities }\end{array}$} & 01 & $\begin{array}{l}\text { A transition between agricultural and urban land, the samples } \\
\text { collected at this site were treated as input data for the Cam } \\
\text { river before entering residential areas, ports and industrial } \\
\text { zones }\end{array}$ & Cam River \\
\hline & 04 & $\begin{array}{l}\text { A transition between agricultural land and industrial zones, } \\
\text { coal ports and cement plants, the samples collected at this } \\
\text { site were treated as input data of the Da Bac-Bach Dang river } \\
\text { before entering industrial zones, coal ports and cement plants }\end{array}$ & $\begin{array}{l}\text { Da Bac- } \\
\text { Bach } \\
\text { Dang } \\
\text { River }\end{array}$ \\
\hline \multirow{2}{*}{$\begin{array}{l}\text { Water before } \\
\text { flowing } \\
\text { into the } \\
\text { midstream } \\
\text { area and } \\
\text { being } \\
\text { affected by } \\
\text { domestic } \\
\text { activities } \\
\text { or the } \\
\text { mangrove } \\
\text { forest system }\end{array}$} & 02 & $\begin{array}{l}\text { A crowded residential area with a fishing ports and building } \\
\text { materials store yard. The samples collected at this area were } \\
\text { used to assess the level of pollution discharged from ports and } \\
\text { urban areas by making comparisons with the results of location } \\
01 \text { at high and low tide times }\end{array}$ & Cam River \\
\hline & 05 & $\begin{array}{l}\text { An area with the densest and largest mangrove, located along } \\
\text { both sides of the Da Bac-Bach Dang river. Samples collected } \\
\text { at this site would provide information on water quality before } \\
\text { flowing through the mangrove (upstream of the mangrove } \\
\text { forest) }\end{array}$ & $\begin{array}{l}\text { Da Bac- } \\
\text { Bach } \\
\text { Dang } \\
\text { River }\end{array}$ \\
\hline
\end{tabular}


Table 3. Continued

\begin{tabular}{|c|c|c|c|}
\hline $\begin{array}{l}\text { River } \\
\text { location }\end{array}$ & $\begin{array}{l}\text { Sampling } \\
\text { site }\end{array}$ & Description & Note \\
\hline \multirow{2}{*}{$\begin{array}{l}\text { The stream } \\
\text { after flowing } \\
\text { through a } \\
\text { crowded } \\
\text { urban area } \\
\text { or mangrove } \\
\text { forest }\end{array}$} & 03 & $\begin{array}{l}\text { After flowing through the urban areas, ports and industrial } \\
\text { zones, an outlet of the Cam river before joining Da Bac-Bach } \\
\text { Dang river at Bach Dang bridge. Samples collected at this site } \\
\text { would provide information on the levels of pollution caused by } \\
\text { residential activities, ports and industrial zones }\end{array}$ & Cam River \\
\hline & 06 & $\begin{array}{l}\text { An outlet of the Da Bac-Bach Dang river, after passing through } \\
\text { the mangroves. Samples collected at this site would help in } \\
\text { assessing the ability of mangroves to dissolve organic and } \\
\text { inorganic pollutants }\end{array}$ & $\begin{array}{l}\text { Da Bac- } \\
\text { Bach } \\
\text { Dang } \\
\text { River }\end{array}$ \\
\hline $\begin{array}{l}\text { Downstream } \\
\text { where the } \\
\text { two rivers } \\
\text { merge into } \\
\text { one as the } \\
\text { Cam river }\end{array}$ & 07 & $\begin{array}{l}\text { Samples collected from the estuary were compared with other } \\
\text { locations at high and low tides to assess the levels of pollutants } \\
\text { being discharged into the sea and the impacts of seawater } \\
\text { movement on the fluctuations in pollutant content }\end{array}$ & \\
\hline
\end{tabular}

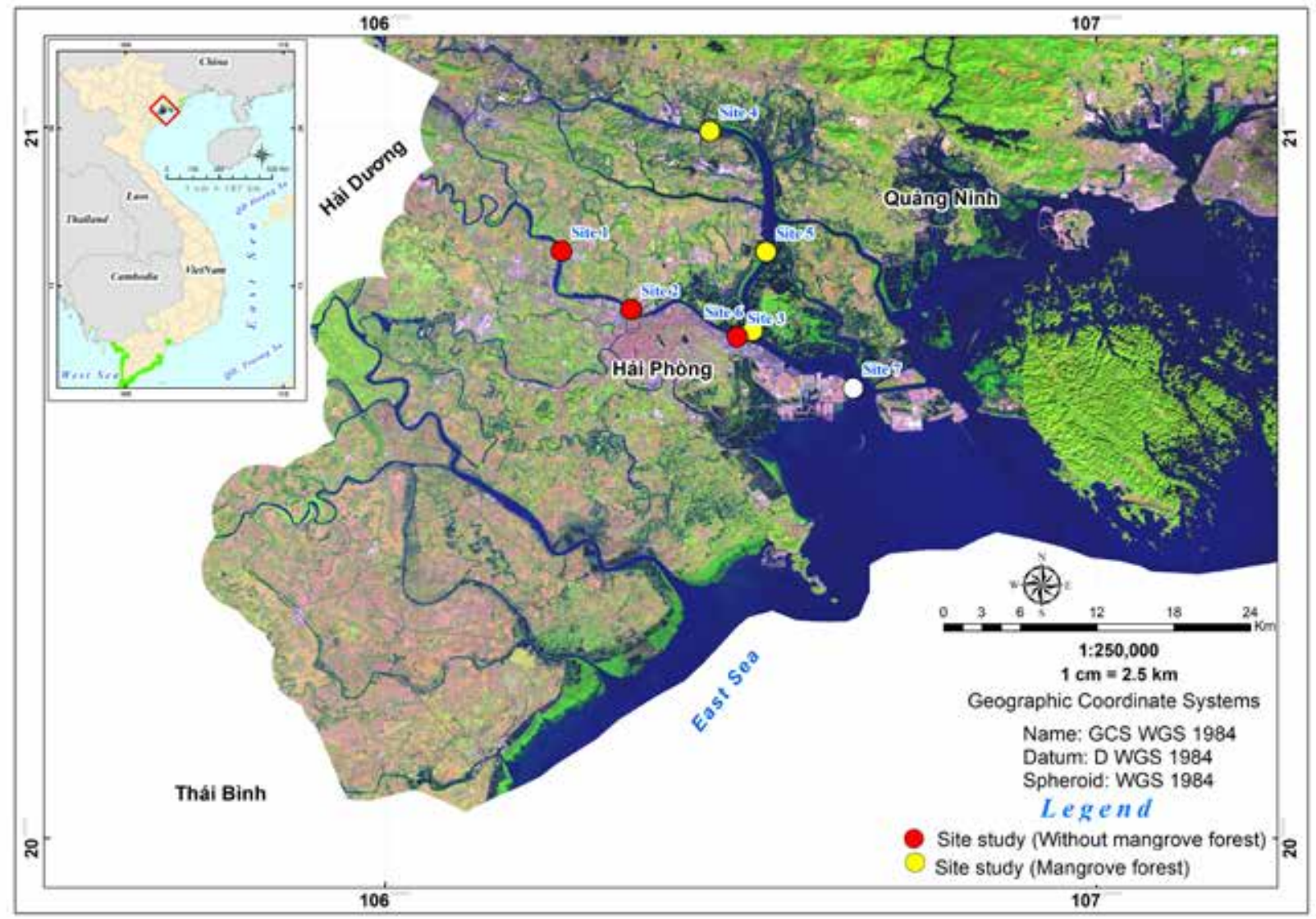

Figure 2. Sample collection sites on the Cam River (without mangroves) and Da Bac-Bach Dang River (with mangrove forest). 


\subsection{Orientation of sampling and data collection}

General principles: Data will be collected on the following:

- Samples used for assessment should include samples of water, suspended matter, sediment, and plant tissue

- Samples should be collected from forest areas near pollution sources and far away from pollution sources (downstream)

- Filtered water (filtrate), suspended matter, and sediment samples from the estuary (with the distance increasing from the mangrove toward the estuary) and strongly affected by seawater should also be collected.

In water, metal(loid)s are partitions between dissolved and suspended forms. The partitioning between these two forms is influenced by various physical, chemical and biological factors. But in many cases, it depends strongly on the properties and content of suspended matter, changes in salinity, structures and sizes of suspended particles, $\mathrm{pH}$ value, dissolved oxygen, flocculation ability, etc. Therefore, samples to assess level of contamination and identify pollution sources should be collected of the following:

- For pollution sources that do not directly drain into the main river but through small canals: filtrate water, suspended matter at low tide, and sediment along the canals before flowing into the main river

- For pollution sources that are adjacent to the main river and drain into the mangrove before being discharged into the sea: filtrate water, suspended matter, and sediment that are near the pollution sources

- In the mangrove: sediment cores of $50 \mathrm{~cm}$ to $100 \mathrm{~cm}$ in length from the mudflat to the inner forest to assess the degree of metal(loid) accumulation and metal(loid) stocks at different mangrove stands and different depth of the sediment

- Bioaccumulation: simultaneously with sediment sampling, the roots, barks, branches, and leaves of mangrove trees should be collected to evaluate their capacity to accumulate metal(loid)s.

Frequency of sample collection: since water quality is influenced by many factors, including natural and anthropologic activities and may change over time, within the given time frame and financial availability, the sample collection in Hai Phong was carried out as follows:

- Samples were collected in two periods (the dry and rainy season): from November to April; and May to December, respectively.

- Samples were collected during high and low tides; from the lowest to the highest tide marks and vice versa.

- For each half cycle of the semi-diurnal regime, the water samples and suspended matters were collected six times a day at two-hour intervals.

- The total number of collected samples was 12 (depending on the budget for analysis, samples could be collected in duplicate or triplicate for each sample collection). 


\subsection{In situ sample collection and storage}

The method for the collection of suspended matter, filtrate samples, and sediments in Hai Phong is described in Table 4.

Table 4. Method of sample collection.

\begin{tabular}{|c|c|}
\hline $\begin{array}{l}\text { Type of } \\
\text { sample }\end{array}$ & Method \\
\hline $\begin{array}{l}\text { Suspended } \\
\text { matter and } \\
\text { filtered water }\end{array}$ & $\begin{array}{l}\text { - At each sampling site and time, surface water and } \\
\text { suspended matter were collected in duplicates at a depth } \\
\text { of about } 50 \mathrm{~cm} \text { below the water-air interface during } 12 \\
\text { hours of the half tidal cycle. } \\
\text { - Surface water was transferred into polypropylene (PP) } \\
\text { bottles that were pre-cleaned with } 10 \% \mathrm{HNO}_{3} \text {. } \\
\text { - Samples were then filtered through a } \\
\text { polytetrafluoroethylene (PTFE) membrane with a pore size of } \\
0.2 \mathrm{\mu m} \text { with more and more water volume as so the amount } \\
\text { of suspended matter sampled would be as large as possible. } \\
\text { The filtrates were contained in the } 15 \mathrm{ml} \text { polypropylene } \\
\text { tubes (cleaned with } 10 \% \mathrm{HNO}_{3} \text { before using). }\end{array}$ \\
\hline
\end{tabular}

- At the time of sample collection, physical and chemical parameters, such as salinity level, $\mathrm{pH}$ and DO were measured at the site by using handheld equipment at a depth of around $50 \mathrm{~cm}$ below the water surface. All electrodes were calibrated on the same day prior to sampling.

- Total suspended solids (TSS) were filtered through glass microfiber filter paper (Whatman ${ }^{\circledR} \mathrm{GF} / \mathrm{F} 0.7 \mu \mathrm{m}$ ) which was burned at $900^{\circ} \mathrm{C}$ and weight was determined.

- The TSS on GF/F was used to determine total organic carbon content.

- In addition, unfiltered water was also collected in polyethylene (PE) bottles to analyze the following criteria: TOC, $\mathrm{NH}_{4}^{+}, \mathrm{TN}$, and TP.

- The variability of physical and chemical parameters and the metal(loid) concentrations in water flowing through main tributaries in Hai Phong before reaching the sea were measured to assess water quality. In Hai Phong, based on the characteristics of major domestic activities such as fisheries, industry, and port services, we selected three groups of water quality indices, including group I, group III, and group IV to calculate the WQI.

\section{Storage}

- The samples were acidified with supra pure $\mathrm{HNO}_{3}$ to $\mathrm{pH}$ less than 2 to avoid adsorption of metal(loid)s on the tubes.

- Filters containing suspended matter were placed in a small plastic container covered with a lid.

- The two types of samples were stored in containers with ice before transfer to the laboratory.

- All samples were kept in a cool box before being transfered to the laboratory and then stored at $-18^{\circ} \mathrm{C}$.

- The filters were then dried to a constant mass using a freezer dryer or an oven (at $105^{\circ} \mathrm{C}$ ), then were weighed to determine the amount of suspended matter in the water column and analyze the carbon content.

- The filtrates were immediately acidified with sulfuric acid to $\mathrm{pH}$ below 2 to limit microbial organisms' decomposition and stored in a cool box during sampling and transporting to the laboratory.

- Those parameters were analyzed as soon as possible within 24 hours after being collected at the field or stored at a temperature of $-18^{\circ} \mathrm{C}$ for longer storage.

Sediment $\quad$ - At each sampling site, bottom surface sediments (with 5 $\mathrm{cm}$ layer) were collected with a specialized bucket (Ekman bottom grab sampler).

- Sediments in the mangrove were collected at low tide with a specialized drill (Eijkelkamp gouge auger).

- Parameters of mangrove sediment, including $\mathrm{pH}$ value and the redox potential (Eh) were measured immediately.

- The salinity level was determined after extracting a drop of pore water from the sediment. The $\mathrm{pH}$ was measured with a glass electrode and a pre-calibrated electrode using buffer solutions (NIST scale).

- The redox potential was measured with $\mathrm{Pt}$ and $\mathrm{Ag} / \mathrm{AgCl}$ electrodes (reference electrodes) connected to the meter, which was also periodically checked using the required standard solutions.
- The sediment samples were kept cold in the field.

- In the laboratory, the samples were stored at $-18^{\circ} \mathrm{C}$ before being dried with a freezer dryer.

- The samples were then ground into a fine powder, passed through a $100 \mu \mathrm{m}$ sieve, and stored in a desiccator before analyzing trace metal(loid)s and TOC. 
Table 4. Continued

\begin{tabular}{lll}
\hline $\begin{array}{l}\text { Type of } \\
\text { sample }\end{array}$ & Method & Storage \\
\hline Plant samples & $\begin{array}{l}\text { Leaf samples, including green and senesced leaves under } \\
\text { the surface sediment, were collected with around } 0.5 \mathrm{~kg} \text { of } \\
\text { weight for each type. }\end{array}$ & $\begin{array}{l}\text { The samples were kept in a cool box } \\
\text { during the sampling campaign and } \\
\text { stored at }-18^{\circ} \mathrm{C} \text { in the laboratory } \\
\text { the roots, barks and branches were collected from trees in } \\
\text { the study areas. Each type of sample weighed around } 0.5 \mathrm{~kg} .\end{array}$ \\
& $\begin{array}{l}\text { using a freezer dryer. } \\
\text { The samples were ground into a } \\
\text { fine powder, passed through a 100 } \\
\mu \mathrm{m} \text { sieve, and stored in a desiccator } \\
\text { before analyzing trace metal(loid)s. }\end{array}$ \\
\hline
\end{tabular}

\subsection{Data analysis}

Various analytical methods were employed to analyze the parameters, which are shown in Table 5. Statistical analysis such as ANOVA and T-test were used to evaluate the average concentration of some physical and chemical parameters and trace metal(loid)s in the water and sediment at the study sites. The results can imply the role of mangroves in reducing pollution and the implications for the development of PFES policies, as summarized in Table 6.

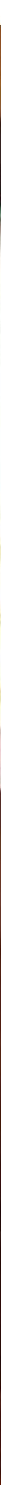


Table 5. Analytical methods in the laboratory.

\begin{tabular}{|c|c|}
\hline Parameter & Analytical methods \\
\hline $\begin{array}{l}\text { Total } \mathrm{NH}_{4}^{+} \text {, total } \mathrm{N} \text {, total } \mathrm{P} \text {, total } \\
\text { organic carbon }\end{array}$ & $\begin{array}{l}\text { - Analysis according to Vietnamese standards sequentially } \\
\text { including TCVN 2615: } 2008 \text { (ISO } 7108 \text { - 1985), TCVN } 8907 \text { - } 2011 \\
\text { (EN } 1131 \text { - 1994) and TCVN } 6202-2008 \text { (ISO 6878 - 2004). } \\
\text { - TOC in suspended matter and sediment was measured on } \\
\text { commercialized analyzers (Shimadzu }{ }^{\oplus} \text { TOC-L combined with a } \\
\text { solid sample combustion unit (SSM-5000A) at } 900^{\circ} \mathrm{C} \text { ). }\end{array}$ \\
\hline $\begin{array}{l}\text { The concentration of dissolved trace } \\
\text { metal(loid)s such as } \mathrm{Al}, \mathrm{Fe}, \mathrm{Mn}, \mathrm{Cr} \text {, } \\
\text { nickel (Ni), tin ( } \mathrm{Sn}), \mathrm{Cu}, \mathrm{Zn} \text {, cobalt } \\
\text { (Co), } \mathrm{Pb}, \mathrm{As}, \mathrm{Cd} \text {, and vanadium (V) in } \\
\text { the filtered water }\end{array}$ & $\begin{array}{l}\text { Dissolved metal(loid)s were directly measured by the } \\
\text { inductively coupled plasma mass spectrometer (ICP-MS). } \\
\text { - The method's accuracy was assessed using a certified reference } \\
\text { material: estuarine water with salinity above } 1 \text { (SLEW-3). }\end{array}$ \\
\hline $\begin{array}{l}\text { The concentration of metal(loid)s in } \\
\text { suspended matter and sediment }\end{array}$ & $\begin{array}{l}\text { - Metal(loid)s were determined by ICP-MS using internal } \\
\text { standards }{ }^{42} \mathrm{Sc}^{75} \mathrm{Ge},{ }^{103} \mathrm{Rh} \text { and }{ }^{197} \mathrm{Au} \text {. } \\
\text { - The accuracy and precision of the analytical method were } \\
\text { ensured by analyzing the reference sample of estuarine } \\
\text { sediment (BCR-277R), which was alternately certified in each } \\
\text { batch of sample digestion. } \\
\text { - All chemicals were analytical grade (Merck) and all containers } \\
\text { and tools were decontaminated by soaking in } 5 \% \mathrm{HNO}_{3} \text { acid for } \\
24 \text { hours and rinsed with deionized water. }\end{array}$ \\
\hline
\end{tabular}

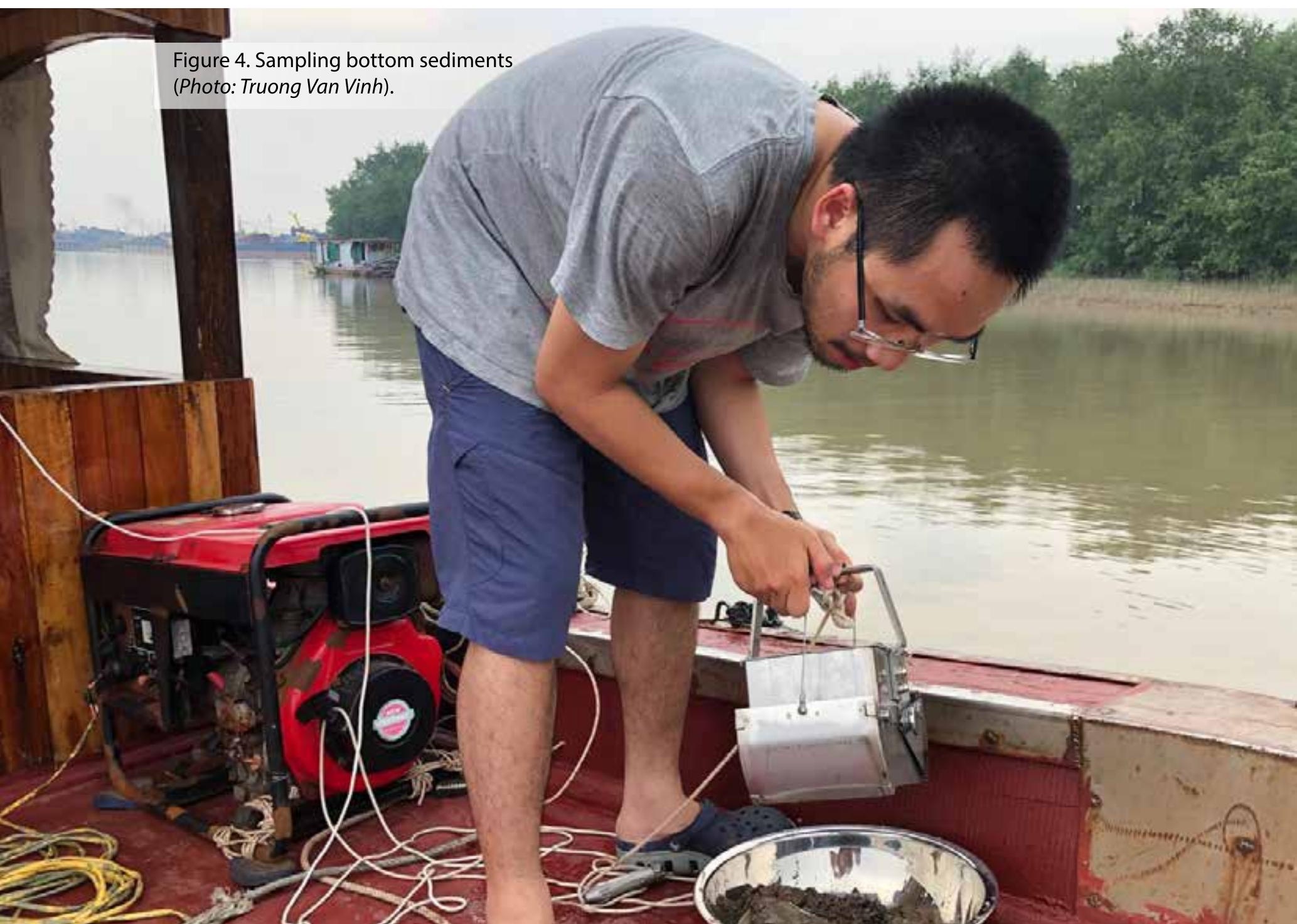


Table 6. Results and implications for the development of a PFES mechanism.

\begin{tabular}{ll}
\hline Tentative results from the assessment & $\begin{array}{l}\text { The implication for the development of } \\
\text { a PFES mechanism }\end{array}$ \\
\hline - $\begin{array}{l}\text { Data of temporal variation over time of } \\
\text { metal(loid) concentrations in water column } \\
\text { of tributaries and estuaries. }\end{array}$ & $\begin{array}{l}\text { To identify target buyers to pay for the mangrove } \\
\text { environmental services. }\end{array}$ \\
$\begin{array}{ll}\text { - } \begin{array}{l}\text { To develop the mechanism for implementing and } \\
\text { monitoring PFES based on environmental indices. }\end{array} \\
\begin{array}{l}\text { different parts of trees (e.g. root, bark, } \\
\text { branch and leaf) and in sediments (beneath } \\
\text { mangrove stands and river bottom). } \\
\text { The ability to retain and transform metal(loid) } \\
\text { s of soil and plants in mangrove forests. }\end{array}\end{array}$ & $\begin{array}{l}\text { To provide scientific evidence of the mangroves' } \\
\text { ability to retain metal(loid)s and pollutants. } \\
\text { To provide a baseline for developing the legal } \\
\text { framework to identify the amount paid for forest } \\
\text { environmental services by the target users and payers. }\end{array}$ \\
\hline
\end{tabular}




\section{Cost of monitoring and assessment}

Concerns for policymakers and project managers are the cost of assessing and monitoring forest environmental services and the effectiveness of PFES in the future. Given 10 percent of the management budget the provincial fund has just received, the real budget for monitoring and evaluating is moderately limited. From the discussions with Hai Phong's fund managers, several government agencies and development programs, the budget for those items, even in provinces with considerable revenue, would only be VND 300 million a year. Hence, the questions here are: How much does it cost to conduct the analytical methods? Are they feasible? Otherwise, what are viable alternatives?

The present study showed that to be able to assess and demonstrate the metal(loid) filtration capacity of mangroves at the seven study sites, the total cost needed was VND 500,000,0000 (Five hundred million VND), including the following items:

(i) Hiring human resources to collect samples, renting boats and power generators, accommodation and stationery expenses

(i) Apparatus and materials: $0.22 \mu \mathrm{m}$ (PTFE) filter, glass microfiber filter, $15 \mathrm{ml} \mathrm{PP}$ tube, $50 \mathrm{ml}$ PP tube, $500 \mathrm{ml}$ plastic (PE) bottles, filtration system including a pump and filtration chamber, plastic bags to collect sediment samples

(i) Analytical costs: Analysis of TOC in suspended matter and sediment, total $\mathrm{NH}_{4}^{+}$, total $\mathrm{N}$, total P in water, trace metal(loid)s in water, suspended matter, sediment, and mangrove plant samples.

This actual amount is limited to conducting formal research, especially when provinces can only afford the maximum amount of VND 300 million a year for monitoring and assessment. To be able to perform the methods, some possible solutions may be considered. These include:

- Reducing the number of samples and study sites: More study sites and samples can yield more accurate and reliable results but can also incur higher costs. A solution for projects and development funds with limited financial capacity is to reduce the number of samples and study sites. Accordingly, to minimize costs for data collection and analysis, the samples could be collected at three locations: (i) entry site, (ii) mangrove dominated site, and (iii) outlet site. Additionally, the samples could be collected only once a year during the dry or rainy seasons. Moreover, reducing the time interval between sampling times also reduces the number of analyses required (e.g. instead of 2-hour intervals between sampling, they could be collected every 3 or 4 hours).

- Conducting data collection every 5 to 10 years: Monitoring and assessing mangrove environmental services reflected in water quality requires longitudinal data. Updating data every 5 to 10 years could reduce the cost significantly compared to frequent monitoring and evaluation and indicate visible water quality changes over long periods of time.

- Combining and sharing the cost of water quality monitoring and evaluation between two adjacent provinces: The studies showed that many basins could flow to two neighboring provinces. Thus, combining and sharing the funds could help to reduce monitoring and evaluation costs.

- Encouraging and providing training for related stakeholders to apply quick assessment methods: In many parts of the world, stakeholders use quick test kits to assess, evaluate, and monitor forest environmental services. They could inform the results to government agencies or the PFES Fund for further evaluation. First, some parameters would be selected for the quick assessment. Training workshops would then be provided to all related stakeholders on how to use regular monitoring and assessment tools. This solution could reduce monitoring and evaluation costs. While experts could collect data every 5 or 10 years, the quick assessment could be conducted annually and provide baseline information for PFES payments. In addition, modeling the correlation between environmental indices could be a potential solution for reducing expenses for annual assessment and evaluation of mangrove services. 
Table 7. Continued

\begin{tabular}{|c|c|c|}
\hline Research objectives & Results & References \\
\hline $\begin{array}{l}\text { The ability to } \\
\text { accumulate and } \\
\text { transfer metal(loid) } \\
\text { s in mangrove } \\
\text { sediments beneath } \\
\text { different mangrove } \\
\text { species, including } \\
\text { Avicennia alba } \\
\text { and Rhizophora } \\
\text { apiculata }\end{array}$ & $\begin{array}{l}\text { - The samples collected from the Can Gio mangrove's } \\
\text { core zone showed that the sediment where metal(loid)s } \\
\text { accumulated were rich in Mn-Fe oxyhydroxides } \\
\text { The dissolution of oxyhydroxides in mangrove } \\
\text { sediments by bacteria during the mineralization of } \\
\text { organic matter under sub-oxidation conditions has } \\
\text { released dissolved trace elements in the pore water. Due } \\
\text { to the sensitivity to redox conditions, the dissolved Fe } \\
\text { and Mn were dominant in the mangrove's pore water } \\
\text { - In addition, the Can Gio mangrove sediment could act } \\
\text { as a natural biochemical reactor for the transformation } \\
\text { of trace metal(loid)s } \\
\text { Depending on the properties of the metal(loid)s and } \\
\text { the redox condition, the dissolved forms of metal(loid) } \\
\text { s resulting from reduction processes precipitated with } \\
\text { new carrier phases, i.e. organic matter, carbonate, } \\
\text { sulfide, and continue to be trapped in mangrove } \\
\text { sediments }\end{array}$ & $\begin{array}{l}\text { (Thanh-Nho et al. } \\
\text { 2018) }\end{array}$ \\
\hline $\begin{array}{l}\text { Metal(loid)s } \\
\text { accumulated in the } \\
\text { roots and leaves } \\
\text { of main mangrove } \\
\text { species }\end{array}$ & $\begin{array}{l}\text { - Trace element accumulation in the tissues of mangrove } \\
\text { plants and snails studied in the Can Gio mangrove } \\
\text { reflected their concentrations in the sediment, their } \\
\text { bioavailability and specific adaptation strategies or } \\
\text { physiological processes of biota } \\
\text { - Mangrove roots can be considered "control points" that } \\
\text { inactivate and restrict some metal(loid)s such as Fe and } \\
\text { As from transferring to above-ground tree parts } \\
\text { - In contrast, Mn and Cu were high translocation elements } \\
\text { as shown in the high translocation factor (TF) results } \\
\text { from roots to leaves } \\
\text { Low biological concentration coefficient (BCF) values } \\
\text { of Cr and Nickel (Ni) in the roots and leaves were due to } \\
\text { their low bioavailability in sediment (they were captured } \\
\text { in a persistent form in sediment) }\end{array}$ & $\begin{array}{l}\text { (Thanh-Nho et al. } \\
\text { 2019) }\end{array}$ \\
\hline $\begin{array}{l}\text { Variation of } \\
\text { trace metal(loid) } \\
\text { s during litterfall } \\
\text { decomposition in } \\
\text { Can Gio mangrove }\end{array}$ & $\begin{array}{l}\text { - Metal(loid)s (Fe, } \mathrm{Al}, \mathrm{Ni}, \mathrm{Cr}, \mathrm{Co}, \mathrm{Cu} \text { and } \mathrm{Zn} \text { ) were enriched } \\
\text { during the decomposition of mangrove litterfall in the } \\
\text { wet and dry seasons } \\
\text { - Those metal(loid)s were absorbed from the water } \\
\text { column at high tide and the forest floor by organic } \\
\text { molecules or decomposed substances from litterfall } \\
\text { - The results of this study have ecological implications on } \\
\text { the nature of trace metal(loid) accumulation and storage } \\
\text { in mangroves }\end{array}$ & (Vinh et al. 2020) \\
\hline
\end{tabular}




\section{Lessons learned}

The methods presented in this document constitute a novel approach based on scientific analysis of trace metal(loid) content to assess the self-purification function of mangroves. In Vietnam, this approach was applied in the Can Gio Mangrove Biosphere Reserve, a unique location with the only water course connecting the center of Ho Chi Minh City to the East Sea (Bien Dong). Previous research in the area have studied: variations in metal(loid)s in dissolved form and suspended matter when they flow through river systems in mangroves; the content of metal(loid)s in river bottom sediment and beneath mangrove tree species; the ability of storage and conversion metal(loid)s in mangrove sediment; and the capacity to accumulate metal(loid)s in the root system and other parts of mangrove trees (Table 7).

Those studies' findings have contributed a better understanding of mangrove environmental services in general, and metal(loid) accumulations in particular. However, the application of methods used in this study is conditional on forest strip thickness. In the Can Gio mangrove, the forest strip was long and deep enough, which showed the advantage of the methods used. In contrast, mangroves along the river in Hai Phong are relatively small and thin strips have limited capacity for metal(loid) filtration. The flow of metal(loid)s through the mangroves was extremely fast, while they need a relatively long time and sufficient space to ensure decent contact between the forest plants and the flow of pollutants. Therefore, it is important to increase mangrove areas in estuarine mudflats to maximize their potential to accumulate trace metal(loid)s and filter other pollutants.

The methods described in this document undoubtedly have limitations, and the following areas need further consideration:

- Identification of pollution sources: In the context of PFES, an important question needs to be answered: who are the payers for mangrove environmental services, and how much should they pay? For identification purposes we need to know clearly who caused pollution and how much they should pay for doing so. Because water quality degradation may result from different sources, the determination of sources and levels of pollution is critically important. Although the methodology described in this study yielded certain desirable results, in order to determine the exact pollution sources, the isotope ratios of metal(loid)s need to be analyzed. The technique for applying metal(loid) isotope ratio to determine the origin of those metal(loid) $s$ has been demonstrated in previous studies. Isotope ratios of metal(loid)s are analyzed directly on the Multi-collector ICP-MS (MC ICP-MS) or processed to eliminate background effects during analysis if using conventional ICP-MS equipment. The MC ICP-MS is one of the most effective tools for tracing metal(loid)s (through isotope ratio analysis) from agricultural and industrial activities. As are no MC ICP-MS machines in Vietnam as yet, we can only analyze the isotope ratios of some metal(loid)s using conventional ICP-MS equipment. The stable isotope analysis of ${ }^{13} \mathrm{C}$ and ${ }^{15} \mathrm{~N}$ and those of metal(loid) isotope ratios can partly demonstrate their origin.

- Overall evaluation from the landscape perspective: Results found in Hai Phong showed that soil erosion and pollution on one side of a river can influence the other side. For example, when erosion occurs in Hai Phong, the stream would deposit on the other bank in Quang Ninh province. As a result, while the area of mangroves in Hai Phong falls, the area in Quang Ninh province gradually expands. Consequently, a landscape approach is required and the identification of buyers of mangrove environmental services may go beyond the borders of one area (province). 


\section{Conclusion}

The development of a payment for environmental services mechanism for mangroves, especially for water filtration, can be supported by applying the methodology presented in this document to determine revenue sources and demonstrate how mangroves provide various environmental services. However, the accuracy of the results depends strongly on natural factors, such as the density of the mangroves, as well as the budget for monitoring and assessment and the skills to employ the methodology. Capacity building for related stakeholders, assessment in a specific time interval (e.g. every 5 years instead of annually); integration of various measures and techniques to reduce costs, and applying landscape-based assessment methods could all scale up the implementation of the methodology.

The results obtained from this methodology in the Can Gio mangrove and in Hai Phong provide highly reliable data for policymakers and organizations on mangrove protection and management in Vietnam. They also meet the request of relevant government ministries for research activities and scientific evidence of the pilot implementation of payment for mangrove environmental services. Existing data on mangroves in the Can Gio mangrove and in Hai Phong also provide baseline information for comparing the impacts of PFES in the future. 


\section{References}

Agoramoorthy G, Chen FA and Hsu MJ. 2008. Threat of heavy metal pollution in halophytic and mangrove plants of Tamil Nadu, India. Environ Pollut 155(2), 320-326.

Berner RA and Raiswell R. 1983. Burial of organic carbon and pyrite sulfur in sediments over Phanerozoic time: A new theory. Geochimica et Cosmochimica Acta 47(5), 855-862.

Chen CW, Kao C-M, Chen C-F and Dong C-D. 2007. Distribution and accumulation of heavy metals in the sediments of Kaohsiung Harbor, Taiwan. Chemosphere 66(8), 1431-1440.

Cheng $\mathrm{H}$, Wang $\mathrm{M}$, Wong MH and Ye Z. 2013. Does radial oxygen loss and iron plaque formation on roots alter $\mathrm{Cd}$ and $\mathrm{Pb}$ uptake and distribution in rice plant tissues? Plant and Soil 375(1-2), 137-148.

Costa-Boddeker S, Hoelzmann P, Thuyen LX, Huy HD, Nguyen HA, Richter O and Schwalb A. 2017. Ecological risk assessment of a coastal zone in Southern Vietnam: Spatial distribution and content of heavy metals in water and surface sediments of the Thi Vai Estuary and Can Gio Mangrove Forest. Mar Pollut Bull 114(2), 1141-1151.

Defew LH, Mair JM and Guzman HM. 2005. An assessment of metal contamination in mangrove sediments and leaves from Punta Mala Bay, Pacific Panama. Mar Pollut Bull 50(5), 547-552.

Dragović S, Mihailović N and Gajić B. 2008. Heavy metals in soils: Distribution, relationship with soil characteristics and radionuclides and multivariate assessment of contamination sources. Chemosphere 72(3), 491-495.

Dunbabin JS and Bowmer KH. 1992. Potential use of constructed wetlands for treatment of industrial wastewaters containing metals. Science of The Total Environment 111(2-3), 151-168.

Hakanson L. 1980. An ecological risk index for aquatic pollution control: A sedimentological approach. Water Research 14(8), 975-1001.

Kadlec R, Knight R, Vymazal J, Brix H, Cooper P and Haberl R. 2000. Constructed wetlands for pollution control: Processes, performance, design and operation, IWA publishing.

Kamaruzzaman BY, Rina Sharlinda MZ, Akbar John B and Siti Waznah A. 2011. Accumulation and distribution of lead and copper in Avicennia marina and Rhizophora apiculata from Balok Mangrove Forest, Pahang, Malaysia. Sains Malaysiana 40(6), 555-560.

MacFarlane G, Pulkownik A and Burchett M. 2003. Accumulation and distribution of heavy metals in the grey mangrove, Avicennia marina (Forsk.) Vierh.: Biological indication potential. Environ Pollut 123(1), 139-151.

MacKenzie RA, Foulk PB, Klump JV, Weckerly K, Purbospito J, Murdiyarso D, Donato DC and Nam VN. 2016. Sedimentation and belowground carbon accumulation rates in mangrove forests that differ in diversity and land use: A tale of two mangroves. Wetlands Ecology and Management 24(2), 245-261.

Marchand C, Baltzer F, Lallier-Vergès E and Albéric P. 2004. Pore-water chemistry in mangrove sediments: Relationship with species composition and developmental stages (French Guiana). Marine geology 208(2-4), 361-381.

Marchand C, Fernandez JM and Moreton B. 2016. Trace metal geochemistry in mangrove sediments and their transfer to mangrove plants (New Caledonia). Science of The Total Environment 562, $216-227$.

Noncent D, Strady E, Némery J, Thanh-Nho N, Denis H, Mourier B, Babut M, An NT, Tuyet NTN, Marchand C, Desmet M, Tu TA, Aimé J, Gratiot N, Tuc DQ and Dan NP. 2020. Sedimentological and geochemical data in bed sediments from a tropical river-estuary system impacted by a developing megacity, Ho Chi Minh City, Vietnam. Data in Brief, 10.1016/j.dib.2020.105938, 105938.

Pham TT, Hoàng TL, LCĐ T, CN H, MH H, TU H, TT HT, KN NN, DT N, VV T and TN N. 2020. Who will buy? Potential buyers for mangrove environmental services in Vietnam. Cifor.org No. 291.

Salomons W, Kerdijk H, Van Pagee H, Klomp R and Schreur A. 1988. Behaviour and impact assessment of heavy metals in estuarine and coastal zones. Metals in coastal environments of Latin America, Springer, 157-198. 
Sinex SA and Wright DA. 1988. Distribution of trace metals in the sediments and biota of Chesapeake Bay. Mar Pollut Bull 19(9), 425-431.

Strady E, Tuc DQ, Némery J, Nho NT, Guédrone S, Sang NN, Denis H and Dan NP. 2017. Spatial variation and risk assessment of trace metals in water and sediment of the Mekong Delta. Chemosphere 179, 367-378.

Sundaramanickam A, Shanmugam N, Cholan S, Kumaresan S, Madeswaran P and Balasubramanian T. 2016. Spatial variability of heavy metals in estuarine, mangrove and coastal ecosystems along Parangipettai, Southeast coast of India. Environ Pollut 218, 186-195.

Taylor SR. 1964. Abundance of chemical elements in the continental crust: A new table. Geochimica et cosmochimica Acta 28(8), 1273-1285.

Thanh-Nho N, Marchand C, Strady E, Huu-Phat N and Nhu-Trang T-T. 2019. Bioaccumulation of some trace elements in tropical mangrove plants and snails (Can Gio, Vietnam). Environ Pollut 248, 635-645.

Thanh-Nho N, Marchand C, Strady E, Vinh T-V and Nhu-Trang T-T. 2018. Metals geochemistry and ecological risk assessment in a tropical mangrove (Can Gio, Vietnam). Chemosphere 219, 365-382.

Thanh-Nho N, Strady E, Nhu-Trang TT, David F and Marchand C. 2017. Trace metals partitioning between particulate and dissolved phases along a tropical mangrove estuary (Can Gio, Vietnam). Chemosphere 196, 311-322.

Tomlinson D, Wilson J, Harris C and Jeffrey D. 1980. Problems in the assessment of heavy-metal levels in estuaries and the formation of a pollution index. Helgoländer meeresuntersuchungen 33(1), 566-575.

Vinh TV, Allenbach M, Linh KTV and Marchand C. 2020. Changes in leaf litter quality during its decomposition in a tropical planted mangrove forest (Can Gio, Vietnam). Frontiers in Environmental Science 8.

Wedepohl KH. 1995. The composition of the continental crust. Geochimica et Cosmochimica Acta 59(7), 1217-1232.

Wood TS and Shelley ML. 1999. A dynamic model of bioavailability of metals in constructed wetland sediments. Ecological Engineering 12(3-4), 231-252.

Yim M and Tam N. 1999. Effects of wastewater-borne heavy metals on mangrove plants and soil microbial activities. Mar Pollut Bull 39(1), 179-186.

Yu .-C, Tsai L-J, Chen S-H and Ho S-T. 2001. Chemical binding of heavy metals in anoxic river sediments. Water Research 35(17), 4086-4094.

Zhang J and Liu C. 2002. Riverine composition and estuarine geochemistry of particulate metals in China-weathering features, anthropogenic impact and chemical fluxes. Estuarine, Coastal and Shelf Science 54(6), 1051-1070. 


CIFOR Working Papers contain preliminary or advance research results on tropical forest issues that need to be published in a timely manner to inform and promote discussion. This content has been internally reviewed but has not undergone external peer review.

This document aims to provide an understanding of the scientific methodology that can be employed to demonstrate, monitor and assess mangrove-relevant environmental services by using case studies of mangroves in Hai Phong City and the Can Gio district of Ho Chi Minh City in Vietnam. In addition to previous work, this methodology evaluates the water purification services of mangroves in the context of existing policies on payment for forest environmental services in Vietnam, and discusses lessons learned, and funding requirements for effective assessment, evaluation and monitoring of the service. The findings contribute to identifying users and buyers of mangrove environmental services and developing implementation and monitoring mechanisms for payment for forest environmental services (PFES) through the application of environmental indices. The document is made in the hope that future studies can apply its methodology in other regions of the country to develop a database for evaluating the roles of mangroves throughout Vietnam.

RESEARCH PROGRAM ON Forests, Trees and Agroforestry
The CGIAR Research Program on Forests, Trees and Agroforestry (FTA) is the world's largest research for development program to enhance the role of forests, trees and agroforestry in sustainable development and food security and to address climate change. CIFOR leads FTA in partnership with Bioversity International, CATIE, CIRAD, ICRAF, INBAR and TBI.

FTA's research is supported by CGIAR Fund Donors: cigar.org/funders/

\section{cifor.org | forestsnews.cifor.org}

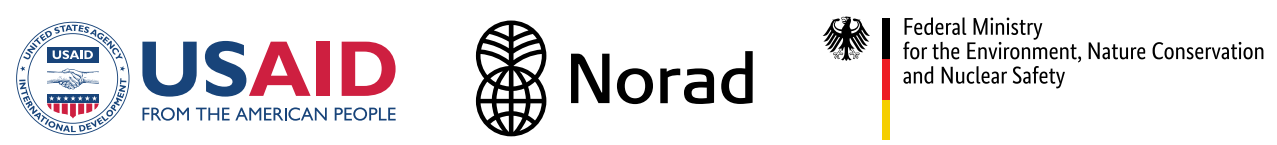
developing partners' capacity, and actively engaging in dialogue with all stakeholders to inform policies and practices that affect forests and people. CIFOR is a CGIAR Research Center, and leads the CGIAR Research Program on Forests, Trees and Agroforestry (FTA). Our headquarters are in Bogor, Indonesia, with offices in Nairobi, Kenya; Yaounde, Cameroon; Lima, Peru and Bonn, Germany. 